\title{
Divas in Dentistry in Romania
}

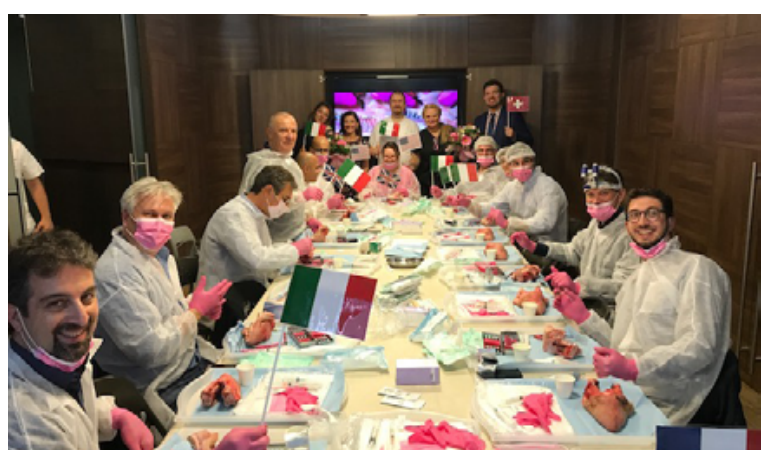

Hands-on section of the GDT Symposium

In September 2017 (21-23), Dr Delia Tuttle DDS, MD organized the first dental symposium in Bucharest, Romania under the slogan "Divas in Dentistry". The event was sponsored by Implant Direct (Danaher, USA), and was organized with the help of several Romanian doctors, among whom, Dr Florin-Eugen Constantinescu, Dr Bogdan Acatrinei, Dr loana Seciu and Dr Diana Ponoran. There were two days of lectures featuring presentations by Dr Tuttle on her "Gum Drop Technique" (GDT) and Dr Anna Luisa Bernotti (Periodontist from Venezuela) on her "V-Y Flap Technique", followed by hands-on sessions where participants practiced on pig jaws. The participants in this course were fifty doctors from around the world, as well as stomatology students from the "Carol Davila" Faculty of Dental Medicine in Bucharest. The countries represented were Belgium, Canada, France, the United Kingdom, Greece, Italy, Spain, Turkey, USA, Venezuela and, of course, Romania. The weekend ended with a cocktail gala which was attended by the participants and other notable guests from Bucharest and abroad, such as Prof Dr Marian-Vladimir Constantinescu DDS, PhD, Editor-in-Chief of the Stomatology Edu Journal and Dr Snježana Pohl DDS, MD, OMS and acclaimed international lecturer from Croatia.

Dr Delia Tuttle DDS, MD, who was born and raised in Romania, near Cluj Napoca, where she graduated from the medical school (2000) as well as the dental school (2005) of the "Iuliu Hatieganu" University ClujNapoca, later emigrated to the USA and graduated from UCLA as a DDS (2009). She is the very heart of the Divas in Dentistry as the founder and moderator of the world wide social movement that brings together the fellowship of women in dentistry (as well as plenty of male supporters now) in order to enrich each other's clinical abilities, encouraging and supporting each other through education courses and by sharing experience and wisdom in practical clinical case presentations. Enjoying impressive social media coverage, this movement has spread all over the world with more than 60,000 followers from the USA, Canada, Europe, Latin America, India, the Middle East and Australia. Dr Tuttle now lectures on her soft tissue techniques and oral implantology case management in the USA and Europe, with invitations extended to her in Asia, Australia, the Middle East and Latin America. Her featured "Gum Drop" technique is a new minimally invasive soft tissue grafting approach, combining minimally invasive incisions with blood derivatives (advanced platelet rich fibrin, A-PRF and injectable platelet rich fibrin, I-PRF) to achieve root coverage and improve tissue biotype. Many root coverage procedures have been described in the literature with varying degrees of success. Autogenous connective tissue grafting remains the gold standard for root coverage and increasing keratinized tissue around natural teeth. This procedure, however, requires a secondary donor site, which can lead to increased pain, morbidity, and limitations in tissue when quadrant or full-arch grafting is needed. Soft-tissue allograft (human cadaver tissue) and xenograft (animal tissue) alternatives have been introduced to overcome these limitations, but the literature has been controversial as to their equality with autogenous connective tissue. Biological factors, such as growth factors and proteins, have been introduced as solo or combination agents to increase wound healing and success rates. In addition, minimally invasive surgical techniques have been used with various materials in an attempt to decrease postoperative discomfort. GDT is a technique that encompasses all of the positive benefits of an autogenous, minimally invasive, and biologically enhanced soft-tissue procedures with a papilla preservation technique which has shown higher patient case acceptance.

Paula Perlea

DMD, PhD

Associate Professor Faculty of Dental Medicine of the

"Carol Davila" University of Medicine and Pharmacy in Bucharest, Bucharest, Romania

DOI: 10.25241/stomaeduj.2017.4(3).news.2 